\title{
FACTORS INFLUENCING THE QUALITY OF BAKERY PRODUCTS
}

\author{
Yu. Trush
}

National University of Food Technologies

\begin{tabular}{l}
$\quad$ Key words: \\
Management \\
Product \\
Enterprise \\
Quality \\
Factors \\
\hline
\end{tabular}

Article history:

Received 15.01.2018

Received in revised form

02.02.2018

Accepted 16.02.2018

Corresponding author:

Ю.Л. Труш

E-mail:

Yuliya633@ukr.net

\begin{abstract}
Quality has a decisive impact on increasing demand and supply and the competitiveness of products, because the higher the demand for products, the higher the supply and competitiveness of the enterprise as a whole. Costs and the price of products will increase depending on its cost and profit ability level, and the greater the profit the efficiency of production and profitability of the enterprise will be higher.

Taking into account all the requirements of the consumer to the product that would satisfy the needs of the market plays an important role in shaping the qualitative properties of the product that consumers want in the consumption process. So, quality depends on the intensity of scientific and technological progress, innovative activity on the introduction of the latest technologies of science and technology, qualifications of personnel, quality of raw materials, components, technical preparation and adjustment of equipment, tools, progressivity of scientific and technical documentation.

But most it depends on the effectiveness of the systems of material and moral incentives for the employees to improve the quality of products. This indicates that the quality of the final product really depends on a number of components which the manufacturer must constantly focus on. Among them there are following: definition of market needs (quality of consumer choice); product design quality; quality of raw materials that came into production; quality of production process; compliance of the quality of the final product with the requirements of the project; quality after sales service.

The main factors influencing the quality of bakery products in the quality management system at all stages of the product life cycle are considered, and take place at the forefront of its formation. The basic clustering of factors in the enterprises of bakery field and their effects on the quality of bakery products are investigated.
\end{abstract}




\title{
чИннИкИ впливу
}

\section{НА ЯКІСТЬ ХЛІБОБУЛОЧНОї ПРОДУКЦІї}

\author{
Ю.Л. Труш \\ Національний університет харчових технологій
}

Якість має вирішальний вплив на підвищення попиту $і$ пропозиції та конкурентоспроможність продукиії, адже чим вищий попит на продукиію, тим вища пропозиція та конкурентоспроможність підприємства в цілому. Витрати й ціна на продукцію будуть зростати залежно від ї̈ собівартості та рівня рентабельності, а чим більшим буде прибуток - тим вищою буде ефективність виробництва й прибутковість роботи підприємства.

Урахування всіх вимог спожсивача до продукту, щзо б задовольняли потреби ринку, відіграють важливу роль при формуванні якісних властивостей продукту, які бажають отримати споживачі в прочесі споживання. Отже, якість залежить від інтенсивності науково-технічного прогресу, інновачійної діяльності з впровадження новітніх технологій науки та техніки, кваліфікаиії кадрів, якості сировини, матеріалів, комплектуючих виробів, технічної підготовки і налагодження обладнання, інструментів, прогресивності науково-технічної документації.

Проте найбільше якість залежить від ефективності систем матеріального й морального стимулювання прачівників за підвищення якості продукиії. Це свідчить про те, що якість кінцевої продукиії дійсно залежить від иілої низки складових, на яких виробник повинен постійно зосереджувати увагу. Серед них виділяють такі: визначення потреб ринку (якість вибору споживача); якість проектування продукту; якість сировини, яка надійшла у виробництво; якість процесу виробництва; відповідність якості кінцевої продукиії вимогам проекту; якість після продажного обслуговування.

У статті розглянуто основні чинники, які впливають на якість хлібобулочної продукиї в системі менеджменту якістю на всіх стадіях життевого ииклу продукиї і мають місие на всіх стадіях ї̈ формування. Досліджено основну класифікацію чинників на підприємствах хлібобулочної галузі та проаналізовано їх наслідки впливу на якість хлібобулочної продукиії.

Ключові слова: управління, продукт, підприсмство, якість, чинники.

Постановка проблеми. Значний вплив на якість способу життя має матеріальне середовище - якість товарів і послуг. У зв'язку з цим проблема якості продукції та послуг не втрачає своєї актуальності. Вона має стратегічний характер, а процес удосконалення якості залежить від багатьох чинників впливу. Він необхідний не тільки для отримання максимального прибутку від реалізації товарів, а, головне, для суспільства та забезпечення його інтересів в цілому. Тому саме аналіз чинників повинен здійснюватися для того, щоб оцінити економічні умови, до яких повинна адаптуватися система менеджменту якості на підприємствах хлібопекарської галузі в Україні та функціонувати паралельно з ними ефективно. 
Аналіз останніх досліджень і публікацій. Питання, пов'язані з аналізом чинників, які впливають на якість хлібобулочної продукції, завжди залишаються популярними серед науковців, аудиторів системи менеджменту якості, інших зацікавлених сторін. Їх постійне дослідження свідчить про те, що підприємство значною мірою залежать від чинників, вплив яких породжує внутрішні зміни в системі управління якістю. Вирішення таких питань дасть змогу створити надійне підгрунтя для ефективного управління якістю продукції. Доречно зазначити, що невирішеними залишаються питання, які потребують реалізації ефективних заходів 3 метою адаптації підприємства до постійних змін ринкового середовища.

Метою статті є обгрунтування основних чинників, які впливають на якість хлібобулочної продукції, а також аналіз і виявлення їх впливу на хлібобулочну продукцію.

Викладення основних результатів дослідження. Якість продукції значною мірою впливає на ефективність функціонування підприємств і залежить від великої кількості чинників організаційного, технічного, економічного, соціального та іншого характеру, які мають місце на всіх стадіях іiі формування: проектування-виробництво-споживання. Тому їх умовно можна поділити на групи залежно від характеру виробництва та сфери діяльності. Через розбіжності в поглядах існують різні підходи до класифікації чинників [3]. Однак єдиного переліку чинників у сучасних економічних джерелах не існує. Це впливає на подальші наукові експерименти і породжує інтерес дослідників до їх аналізу. Оскільки умови, від яких залежить виробництво продукції, мають тенденції до коливань, то чинники, які діють на якість, також змінюються.

Проведені дослідження на підприємствах 3 виробництва хліба та хлібобулочних виробів (виробничий цех № 10 ПАТ «Київхліб» і виробничий цех № 12 ПАТ «Київхліб») показали, що основні чинники, які впливають на якість хлібобулочних виробів у системі менеджменту якості, технічні, організаційні, соціально-економічні, правові. Так, на якість хлібобулочної продукції впливають рівень матеріально-технічної бази, якість сировини, якість роботи працівників, рівень організації виробництва, рівень контролю якості тощо.

Розглянемо вплив кожного із вищеперерахованих чинників, але зауважимо, що зазначений вище чинник - рівень контролю якості, окремо не виділений через відсутність однозначних даних на підприємствах галузі, яка досліджується. Він певною мірою впливає й на інші чинники та має тісний взаємозв'язок з ними. [1]. Отже, згрупуємо їх та відобразимо схематично в таблиці [3].

Рівень матеріально-технічної бази характеризується технічною готовністю обладнання до роботи, технологічною оснащеністю та рівнем обслуговування виробництва, а також ступенем його автоматизації. Аналіз досліджень показав, що цей чинник має вирішальне значення для забезпечення високої якості продукції, тому що він спричиняє в середньому $43 \%$ браку та дефектів [5].

За 2012-2014 pр. динаміка цього чинника на підприємствах, які виробляють хлібобулочну продукцію, змінювалася постійно. Так, наприклад, в 
2012 році спостерігався ріст втрат, а потім різкий спад. Це обумовлено технічним переоснащенням виробництва, починаючи з кінця 2012 року, після чого втрати внаслідок низького рівня роботи обладнання помітно зменшилися. Незважаючи на це, на даний момент рівень розглянутого чинника залишається високим - 31,8\%, що пов'язано з моральним і фізичним зносом обладнання [7].

\section{Таблиця. Чинники впливу на якість хлібобулочної продукції}

\begin{tabular}{|c|c|}
\hline $\begin{array}{l}\text { Чинники впливу на якість } \\
\text { хлібобулочних виробів }\end{array}$ & Характеристика чинників \\
\hline Рівень матеріально-технічної бази & $\begin{array}{c}\text { Технологічне оснащення, автоматизація } \\
\text { виробництва, технологічне обслуговування, знос } \\
\text { виробництва. }\end{array}$ \\
\hline Якість сировини & $\begin{array}{c}\text { Відповідність нормативним вимогам, умови } \\
\text { зберігання, умови транспортування. }\end{array}$ \\
\hline Якість роботи працівників & $\begin{array}{c}\text { Трудова дисципліна, відношення до роботи, рівень } \\
\text { кваліфікації кадрів, технологічна дисципліна. }\end{array}$ \\
\hline Рівень організації виробництва & $\begin{array}{c}\text { Структура виробництва, умови праці, ритмічність і } \\
\text { своєчасність поставок сировини, методи } \\
\text { стимулювання праці. }\end{array}$ \\
\hline Рівень контролю якості & $\begin{array}{c}\text { Організація роботи підрозділів, відповідальність за } \\
\text { якість, засоби контролю, оперативність, } \\
\text { систематичність, надійність. }\end{array}$ \\
\hline Інші чинники & $\begin{array}{c}\text { Виробництво експериментальних партій нової } \\
\text { продукції, апробація нової продукції. }\end{array}$ \\
\hline
\end{tabular}

Якість роботи працівників включає перш за все рівень кваліфікації персоналу, задіяного у виробництві продукції, досвід роботи, професійну майстерність кадрів, а також загальне ставлення до роботи і зацікавленість у високих результатах, підвищення рівня кваліфікації, дотримання трудової та технологічної дисципліни, наявність високої культури виробництва.

Ступінь впливу цього чинника також високий, а на втрати від нього припадає від $26 \%$ до $36 \%$ загального браку, причому в останні роки спостерігається ріст таких втрат. Так, наприклад, у 2013 році він мав найбільше значення за останні роки, і воно переважає рівень технічного [6].

Дослідження складу та кваліфікації робочого персоналу показало, що на підприємствах, які виробляють хлібобулочну продукцію, почали приділяти більше уваги підвищенню кваліфікації кадрів (більшість працівників підвищують свій рівень кваліфікації в процесі роботи ). Велика кількість дефектів і браку при цьому пов'язана 3 недостатнім контролем технологічного процесу виробництва, що проявляється в порушенні рецептури виробів, неповній вазі та неправильній формі для випікання, неуважності на робочому місці та низькому контролі за роботою обладнання. Збільшення таких дефектів свідчить про низький рівень процесу контролю над виробництвом, що в кінцевому результаті впливає на якість готової продукції.

Рівень організації виробництва характеризує ефективну організацію виробничого процесу в цілому, включаючи структуру виробництва, умови праці, 
своєчасне надходження сировини та матеріалів, безперебійність роботи обладнання, а також методи матеріального й морального стимулювання праці.

Частка цього чинника в структурі втрат від браку з 2012 по 2014 рік коливався від 11 до 17\%. Найбільшого значення він досяг у 2013 році, після чого зменшився.

За оцінкою спеціалістів, які працюють на досліджуваних підприємствах хлібобулочної галузі (виробничий цех № 10 ПАТ «Київхліб» і виробничий цех № 12 ПАТ «Київхліб»), рівень організації виробництва досить високий, забезпечена своєчасність поставок сировини, безперебійність роботи обладнання, необхідні умови праці. Поява дефектів обумовлена частково зовнішніми причинами - проблема доставки сировини, і більшою мірою — невисоким рівнем контролю якості робіт.

Такі причини мають прямий вплив на організацію виробництва, i тому відбувається більшість випадків браку, а зменшення рівня контролю над якістю робіт, як і в попередньому чиннику, призводить до його зростання. Цей чинник впливає на систему менеджменту та якість продукції взагалі. Тому необхідно відстежувати та враховувати зміни, які він викликає, спостерігати і звертати увагу керівництву підприємства [2].

Чинник «Якість сировини». Основною сировиною для виробництва хлібобулочної продукції на підприємствах є борошно, якість якого, за оцінкою спеціалістів підприємства, на 70\% визначає якість готової продукції.

На підприємствах, що виробляють хліб і хлібобулочні вироби, рівень впливу цього чинника на дефектність продукції відносно невисокий - не перевищує 12\% [8]. Це пов'язано з високою ефективністю вхідного контролю сировини: перевірці підлягає кожна партія сировини, навіть якщо остання купується у відомих, з позитивною репутацією постачальників. Незважаючи на високу якість сировини, окремі партії, які містять приховані дефекти та властивості, що проявляються в процесі надходження у виробництво, в подальшому можуть стати причиною браку. Таке явище трапляється рідко, але щоб запобігти його появі, служба матеріально-технічного повинна регулювати постачання.

Остання група чинників об'єднує чинники, які не ввійшли в попередні групи та пов'язані в основному 3 виробництвом випробуваних партій нової продукції або апробацією нових видів сировини. В середньому цей чинник $є$ причиною браку в 3,5 випадках із 100, що несуттєво порівняно 3 впливом інших та виправдано технологічним процесом виробництва.

Таким чином, із сукупності чинників, що впливають на якість хлібобулочної продукції, першочерговими необхідно вважати чотири чинники, а також чинник контролю якості, який відіграє значну роль для забезпечення високої якості продукції та має безпосередній вплив на інші. Доцільно при цьому підвищувати рівень матеріально-технічної бази виробництва, раціонально своєчасно поновлювати старе та зношене обладнання, систематично покращувати технологічне оснащення виробництва, тому що це найбільше впливає на якість виробів.

Зазначимо, що важливо спрямовувати зусилля на підвищення якості роботи працівників, їх кваліфікацію та професійні навички, дотримуватися трудо- 
вої дисципліни. 3 огляду на це не менш важливими є такі чинники: покращення організації праці, забезпечення безперервного технологічного циклу виробництва. Отже, саме технологам і майстрам потрібно покращувати організацію праці та дотримуватися технологічної дисципліни постійно [8]. Необхідно посилювати контроль за якістю сировини, процесом виробництва, а також підвищувати забезпечення координації контролю на кожному етапі виробничого циклу з підсумковим контролем якості готової продукції, що дасть змогу запобігти появі браку та дефектів. Ефективність такої пропозиції пов'язана з роботою підрозділу, що відповідає за якість. Через це необхідно збільшити його чисельність і покращити організацію роботи в напрямку комплексного контролю.

Отже, для зменшення втрат від браку та підвищення ефективності управління якістю даної продукції необхідно покращити умови пристосування системи управління якістю до постійно змінних основних чинників, що впливають на якість, та зосередитися на усуненні дефектів [9].

Аналіз чинників, що впливають на якість продукції, дає змогу виявити такі основні закономірності управління якістю в системі менеджменту, що демонструють надійні, систематичні причинно-наслідкові зв'язки між ними.

По-перше, це ступінь відповідності якості продукції технічному рівню виробництва та стану матеріально-технічної бази. Тобто якість продукції знаходиться в прямій залежності від цього чинника: чим вищий технічний рівень виробництва, тим більш високоякісна продукція буде вироблятися. А подальше удосконалення якості продукції пов'язане 3 підвищенням рівня виробництва за рахунок модернізації обладнання, впровадження нових технологій і зміцнення матеріально-технічної бази в цілому [4].

По-друге, залежність якості продукції від рівня організації виробництва та пов'язаної з нею якості виконання робіт. Цей чинник важко переоцінити, тому що він відіграє важливу роль, як і технічний чинник. Тож чим краще та ефективніше організовано технологічний процес, забезпечено його безперебійність, необхідні умови, тим вищою буде якість виконання робіт і менше дефектів і браку на підприємстві.

По-третє, взаємозв'язок і пряма залежність рівня якості виконуваних робіт та виготовленої продукції від рівня кваліфікації кадрів [10]. А саме: чим вищий рівень кваліфікації кадрів, тим більш високого рівня якості продукції можна досягнути при інших чинниках (якість сировини, матеріалів, технології виробництва).

У такій ситуації одним із основних напрямків підвищення якості продукції $\epsilon$ підвищення кваліфікації кадрів, трудової й технологічної дисципліни та контролю якості за виготовленою продукцією [7].

Важливою також $є$ ще одна закономірність, пов'язана із забезпеченням високої якості, а точніше, із безперебійністю та комплексністю контролю якості за всіма напрямками: вхідний контроль сировини, контроль технологічного процесу виробництва, готової продукції, продукції після випуску іії 3 виробництва. Чим вища частота та комплексність контролю, тим вища якість кінцевої продукції [9]. 
Отже, необхідно враховувати всі закономірності при управлінні якістю продукції та плануванні заходів для ії підвищення. Матеріали та інформацію про аналіз чинників необхідно доводити до відома персоналу з управління та використовувати при розробці планів організаційно-технічних заходів для підвищення якості продукції, а отже, й ефективності виробництва. Крім того, об’єми та причини браку потрібно вивчати у всіх цехах і відділах підприємства з метою запобігання їх повторенню.

\section{Висновки}

Отже, на якість продукції підприємств хлібобулочної галузі, як і на якість продукції підприємств іншої галузі, постійно впливають різні чинники. Тож якість безперервно залежить від них. Цю закономірність необхідно враховувати при управлінні та плануванні заходів щодо ії підвищення для ефективної діяльності підприємства.

Аналіз чинників, які впливають на якість хлібобулочної продукції в системі менеджменту якості, повинен проводитися систематично. Це дає змогу виявити ряд потенційно можливих загроз, прискорити ї усунення та мінімізувати негативний вплив на систему управління якості хлібобулочної продукції, i, як наслідок, задовольнити всі вимоги споживачів, тому що споживач оцінює якість продукції з точки зору потреб, які для нього першочергові та вкрай необхідні.

Отже, головним стереотипом для підприємств-виробників хлібобулочної продукції є виготовлення продукції більш вищої якості порівняно з конкурентами 3 метою отримання максимального прибутку та закріплення позитивної репутації серед споживачів.

\section{Література}

1. Алєксєєв I.В. Економічний механізм управління розвитком підприємства / І.В. Алєксєєв та інші. - Львів : Світ, 2008.- 354 с.

2. Гнатенко П.А. Практичні аспекти планування якості / Методи менеджменту якості. 2008. — № 6. - С. 22-27.

3. Кабаков Ю.Б. Розробляємо і впроваджуємо СМЯ: крок за кроком / Хлебопекарское и кондитерское дело. - 2007. - № 5. - С. $54-56$.

4. Кочєтов В.В. Методи оцінки конкурентоспроможності продукції і виробництва / Стандарти і якість. - 2007. — № 7. - С. 62-64.

5. Мельник Ю.Ф. Основи управління безпечністю харчових продуктів : навч. посіб. / Ю.Ф. Мельник, В.М. Новиков, Л.С. Школьник. - Київ : Вид-во Союзу споживачів України, 2007. - 297 с.

6. Управління якістю: Навчальний посібник / Р. Бичківський. — Львів : ДУ «Львівська політехніка», 2008. - 329 с.

7. Формування продовольчої безпеки в Україні: регіональний аспект / В.М. Микитюк, О.В. Скидан. - Житомир : ДАУ, 2007. - 248 с.

8. Федотов Л.В. Інтеграція і стандартизація провесно-орієнтованих систем менеджменту / Методи менеджменту якості. - 2005. - № 12. - С. 20-22.

9. Юшин С.О. Методологічні підвалини взаємодоповнення інноваційно-інвестиційної моделі розвитку та системи управління якістю // Економіка: проблеми теорії та практики: Збірник наукових праць. - Випуск 258: в 4-х т. — Т. 2. — Дніпропетровськ : ДНУ, 2009. C. $569-575$.

10. Юшин C.O. Інноватизація та стандартизація аграрного сектора економіки у ринкових координатах: теорія та право // Науковий вісник Національного аграрного університету. - Київ : 2008. - Вип. 131. - С. 20-26. 